\title{
Article \\ Using Mg/Ca Ratios from the Limpet Patella depressa Pennant, 1777 Measured by Laser-Induced Breakdown Spectroscopy (LIBS) to Reconstruct Paleoclimate
}

\author{
Asier García-Escárzaga 1,2,*D), Marina Martínez-Minchero ${ }^{3,4} \mathbb{D}$, Adolfo Cobo ${ }^{3,4,5}$, Igor Gutiérrez-Zugasti ${ }^{6}$, \\ Alvaro Arrizabalaga ${ }^{2}$ and Patrick Roberts ${ }^{1,7}$ (D)
}

1 Department of Archaeology, Max Planck Institute for the Science of Human History, Kahlaische Strasse 10, D-07745 Jena, Germany; roberts@shh.mpg.de

2 Department of Geography, Prehistory and Archaeology, University of the Basque Country (UPV/EHU), C/Tomás y Valiente s/n, 01006 Vitoria-Gasteiz, Spain; alvaro.arrizabalaga@ehu.eus

3 Photonics Engineering Group, Department of TEISA, Edificio I+D+i de Telecomunicaciones, Avda. Los Castros s/n, 39005 Santander, Spain; marina.martinez@unican.es (M.M.-M.); adolfo.cobo@unican.es (A.C.)

4 Instituto de Investigación Sanitaria Valdecilla (IDIVAL), 39005 Santander, Spain

5 CIBER-BBN, Instituto de Salud Carlos III, 28029 Madrid, Spain

6 Instituto Internacional de Investigaciones Prehistóricas de Cantabria (Universidad de Cantabria, Gobierno de Cantabria, Grupo Santander), Edificio Interfacultativo de la Universidad de Cantabria, Avda. Los Castros s/n, 39005 Santander, Spain; fernandoigor.gutierrez@unican.es

Citation: García-Escárzaga, A.; Martínez-Minchero, M.; Cobo, A.; Gutiérrez-Zugasti, I.; Arrizabalaga, A.; Roberts, P. Using Mg/Ca Ratios from the Limpet Patella depressa Pennant, 1777 Measured by Laser-Induced Breakdown Spectroscopy (LIBS) to Reconstruct Paleoclimate. Appl. Sci. 2021, 11, 2959. https://doi.org/10.3390/ app11072959

Academic Editor: Jordi Revelles

Received: 24 February 2021

Accepted: 21 March 2021

Published: 25 March 2021

Publisher's Note: MDPI stays neutral with regard to jurisdictional claims in published maps and institutional affiliations.

Copyright: (c) 2021 by the authors. Licensee MDPI, Basel, Switzerland. This article is an open access article distributed under the terms and conditions of the Creative Commons Attribution (CC BY) license (https:// creativecommons.org/licenses/by/ $4.0 /)$.
7 School of Social Sciences, University of Queensland, St Lucia, QLD 4072, Australia

* Correspondence: garcia-escarzaga@shh.mpg.de

\begin{abstract}
Measurement of the elemental composition of shells is increasingly emerging as an avenue for obtaining high-resolution insights into paleoclimate and past seasonality. Several studies have shown significant correlations between $\mathrm{Mg} / \mathrm{Ca}$ ratios measured on shell carbonate and the sea surface temperature (SST) within which this carbonate was precipitated. However, other investigations have reported large variability in this relationship between species. Therefore, further studies, including taxa previously not considered are still required in order to validate these new species as suitable climate proxies. Here, we measured $\mathrm{Mg} / \mathrm{Ca}$ ratios for limpet Patella depressa Pennant, 1777 samples live-collected in northern Spain for the first time. The elemental ratio was measured using laser-induced breakdown spectroscopy (LIBS), a technique that significantly decreases the time required for sample preparation and increases the number of shells that can be analyzed. In this study, calibration-free LIBS (CF-LIBS) methods were applied to estimate molar concentrations of chemical elements on biogenic calcium carbonate. The $\mathrm{Mg} / \mathrm{Ca}$ ratio evolution along the shell growth axis was compared with stable oxygen isotope $\left(\delta^{18} \mathrm{O}\right)$ profiles obtained from these same limpets and the SST at the place where the mollusk grew to determine if the sequences obtained correctly reflected environmental conditions during the life-span of the mollusk. The results showed a significant correlation between $\mathrm{Mg} / \mathrm{Ca}$ ratio series and both $\delta^{18} \mathrm{O}$ profiles and SST, highlighting the paleoenvironmental and archaeological potential of LIBS analyses on this mollusk species that is frequently found in archaeological contexts in the western Europe.
\end{abstract}

Keywords: archaeology; mesolithic; N Spain; mollusk shells; marine environment; spectroscopy

\section{Introduction}

There has long been a keen theoretical and methodological interest in archaeology at elucidating the impacts of climatic and environmental change on hominin behavior, settlement, and culture in different parts of the world at different points of time [1-5], and how this might be mobilized to inform challenges facing our species in the 21st century [6,7]. In western Europe, climate changes have been variously argued to have had deep implications for Neanderthal behavior and eventual extinction [8-10], the tempo and nature of 
human hunter-gatherer settlement across the Last Glacial Maximum and Early-Middle Holocene [11-13], and the arrival and adaptations of the first farmers [14,15]. Crucial to such debates, however, is the ability to develop a set of proxies that can reconstruct the impacts of broader climatic systems on local environments used by past human populations, both marine and terrestrial [16-18]. Furthermore, from a behavioral perspective, some of the most critical climatic changes impact intra-annual seasonality of temperature and rainfall, something that has been notoriously difficult to reconstruct for the past $[19,20]$.

The shells of marine mollusks are routinely found in many archaeological deposits due to littoral resources that were exploited by past hominins at least from the Middle Pleistocene [21-24], but especially during Upper Paleolithic and Mesolithic periods [25-27]. Previous investigations have demonstrated that shell remains can offer very valuable information on human settlement and mobility patterns, as well as on subsistence strategies of these past populations [28-31]. At the same time, shells can also be considered as a particularly relevant paleoenvironmental proxy in the context of exploring past marine conditions [16,32]. Marine mollusk species have very specific environmental requirements and are very sensitive to climate change [33,34]. Warmer conditions during the Early Holocene provoked significant changes in species representation along the Atlantic coasts of Europe compared to the Pleistocene assemblages $[35,36]$. Meanwhile, the current rising of seawater temperatures is provoking a rapid expansion of the northern limit of warm-adapted marine species $[37,38]$. Beyond taxonomic studies, during the last few decades, the isotopic measurement of biogenic carbonates within mollusk shells has been found to provide a highly effective paleothermometer over the course of a mollusk's lifespan $[16,20,39,40]$. Stable oxygen isotope ratios derived from marine mollusk shells $\left(\delta^{18} \mathrm{O}_{\text {shell }}\right)$ are powerful recorders of the seasonal sea surface temperature (SST) variations experienced during the precipitation of carbonate year-round in the past [39,41-43]. Not only that, but isotopic series can be used to define the season(s) when the mollusks were harvested by past hominin groups, thus deciphering seasonal exploitation patterns of this food supply during prehistory [44-47].

Although previous studies on modern marine mollusk shells have shown a high correlation between $\delta^{18} \mathrm{O}_{\text {shell }}$ values and SST [48-51], oxygen isotope fractionation is also influenced by oxygen isotope composition of the seawater $\left(\delta^{18} \mathrm{O}_{\mathrm{sw}}\right)[20,52]$. This represents a significant limitation for paleoreconstructions where $\delta^{18} \mathrm{O}_{\mathrm{sw}}$ values are unknown, while the cost- and time-consuming nature of serial $\delta^{18} \mathrm{O}_{\text {shell }}$ sampling can also be prohibitive. This has led to efforts to develop independent paleotemperature archives. Concentration ratios of some trace elements to calcium have been successfully tested on corals and foraminifera [53-55]. However, despite extensive research on mollusk shells, relatively few studies have shown a clear relationship between the element/Ca ratios obtained and SST [39,56-58], with many reporting a low (or no) correlation between element/Ca ratios and SST in different mollusk species [59-64]. This indicates significant species-specific variability in this regard, as well as divergence in how trace elements are incorporated into carbonate in different habitats [65]. Therefore, more analyses involving new shell taxa and species collected from coastal areas previously not considered are required to better understand trace element precipitation mechanisms and the wide-scale effectiveness of this approach as a past environmental proxy.

In this study, we measured, for the first time, $\mathrm{Mg} / \mathrm{Ca}$ ratios of limpet Patella depressa Pennant, 1777 samples live-collected in northern Spain. This mollusk species was consumed in high numbers by Mesolithic humans during the Early Holocene period, along the Atlantic coast of Europe, representing an important percentage of all shell taxa recovered from shell middens excavated in northern Spain and France [66,67]. Determining if $\mathrm{Mg} / \mathrm{Ca}$ ratios derived from $P$. depressa can be used as a suitable paleothermometer to reconstruct paleoclimate conditions and seasonality would have significant implications for future archaeological and paleoenvironmental investigations. $\mathrm{Mg} / \mathrm{Ca}$ ratios were measured using laser-induced breakdown spectroscopy (LIBS), one of the most novel techniques for measuring element/Ca ratios on shells due to significantly easier sample preparation and 
lower measurement times [57,58,68-70]. A calibration-free LIBS (CF-LIBS) technique [71] was applied in order to estimate the molar concentrations of both chemical elements. This procedure was applied for the first time to marine mollusk shell biogenic carbonates. Although a recent isotopic investigation carried out on this species has shown that $\delta^{18} \mathrm{O}_{\text {shell }}$ derived from this species correctly reflects seasonal temperature variations year-round in northern Spain [72], LIBS-derived $\mathrm{Mg} / \mathrm{Ca}$ ratio could offer significant improvements in relation to $\delta^{18} \mathrm{O}_{\text {shell }}$ as a SST recorder, allowing an increase in the number of shells measured for each stratigraphic unit, as well as the wider accuracy of archaeological conclusions. In order to determine if elemental series measured on P. depressa are a suitable paleothermometer, $\mathrm{Mg} / \mathrm{Ca}$ ratio series obtained were compared with stable oxygen isotope ratio profiles previously obtained from these same four marine mollusk shells [72], as well as with measured SST information at the place where mollusks grew.

\section{Materials and Methods}

\subsection{Modern Shells and Sea Surface Temperature (SST)}

Four P. depressa live-collected limpets were collected at Langre Beach (Cantabria, northern Spain, Figure 1) $\left(43^{\circ} 28^{\prime} 37^{\prime \prime} \mathrm{N}, 3^{\circ} 41^{\prime} 44^{\prime \prime} \mathrm{W}\right)$ on 1 October 2012 , corresponding to the end of the warmer season (i.e., summer). The specimens were gathered from the rocky intertidal shore and they were sacrificed immediately after collection by immersion in boiling water for one minute, thus avoiding further deposition of calcium carbonate. To determine if the LIBS-derived $\mathrm{Mg} / \mathrm{Ca}$ series from these shells are dependent on environmental conditions, they were compared with measured year-round SST variations during the life-span of the mollusks. Daily instrumental SST data were provided by the Spanish Institute of Oceanography (Santander, Cantabria) (Figure 1), which is located close to Langre beach $(<10 \mathrm{~km})$. The salinity conditions of the sea (35.6 $\pm 0.7 \mathrm{PSU})$, as well as the oxygen isotope composition of the seawater $\left(\delta^{18} \mathrm{O}_{\mathrm{sw}}=0.9 \pm 0.2 \%\right.$ [VSMOW] $)$ are similar in both areas, with no influence of continental runoff or sea currents with different salinity levels $[73,74]$.

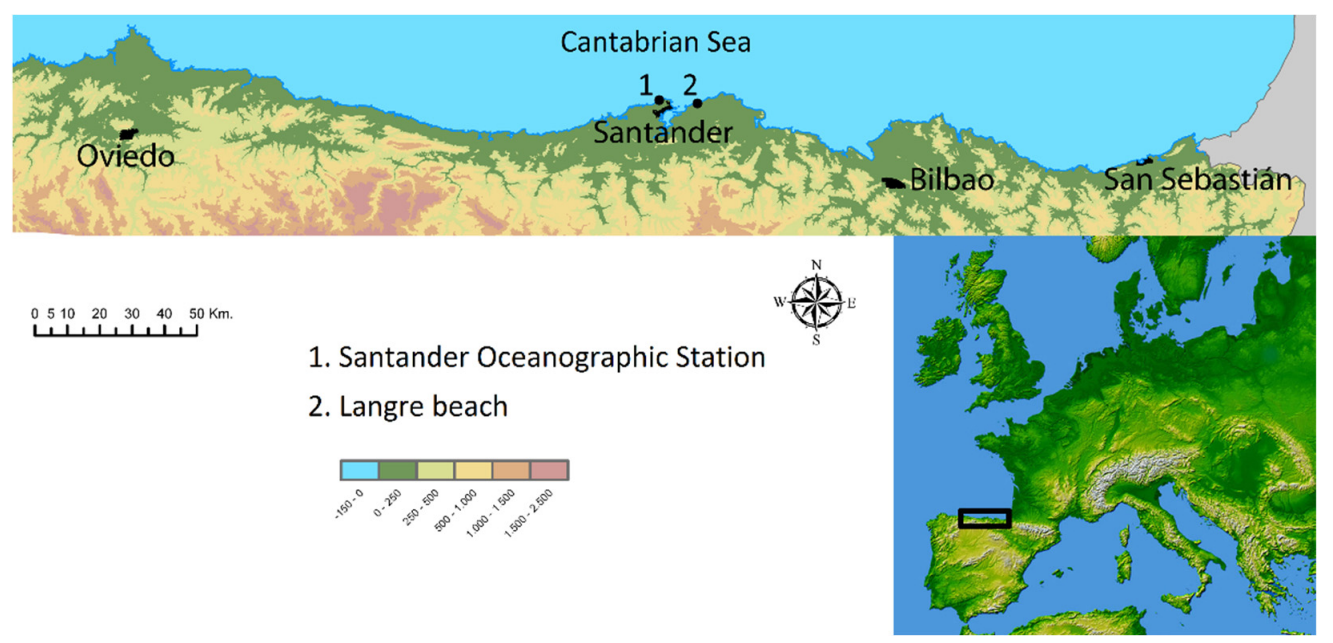

Figure 1. Location of the study area in northern Spain, Santander Oceanographic Station, and Langre beach.

\subsection{LIBS Experimental Set-Up}

LIBS is an atomic emission spectroscopic technique that ablates a small volume of material with a high-energy pulsed laser, creating a plasma. The light emitted from the plasma contains emission lines at different wavelengths depending on the sample composition at the elemental and molecular levels [75]. The $\mathrm{Mg} / \mathrm{Ca}$ ratios reported in this work were obtained from the processing of $\mathrm{Mg}$ and Ca lines' emission intensities. The experimental setup (Figure 2) consisted of a Nd:YAG laser (Lotis LS-2134D) operating at a wavelength of $1064 \mathrm{~nm}$, with $16 \mathrm{~ns}$ pulse width and $10 \mathrm{~Hz}$ repetition rate. The pulse 
energy was set to $40 \mathrm{~mJ}$. The laser spot was focused with a lens of $75 \mathrm{~mm}$ focal length, producing a crater of $200 \mu \mathrm{m}$ diameter and $0.2 \mu \mathrm{m}$ depth (average) for each laser shot. The light emission from the plasma was collected with an optical fiber $(800 \mu \mathrm{m}$ diameter $)$ coupled to a bundle of 8 fibers for each channel of an Avantes ULS2048-USB2-RM CCD spectrometer with a total wavelength range from 178 to $889 \mathrm{~nm}$, and a resolution from 0.015 to $0.06 \mathrm{~nm}$. The capture window to collect the plasma-emitted light was set to start 5 microseconds after the laser shot, with a length of 1 millisecond (the minimum capture time for this non-gated spectrometer). A trough-lens vision system with a CCD camera allowed the inspection of the sample surface. The sample position was controlled by a motorized $\mathrm{XYZ}$ positioner, programed to follow a measurement path along the shell surface, which is described in the next section.

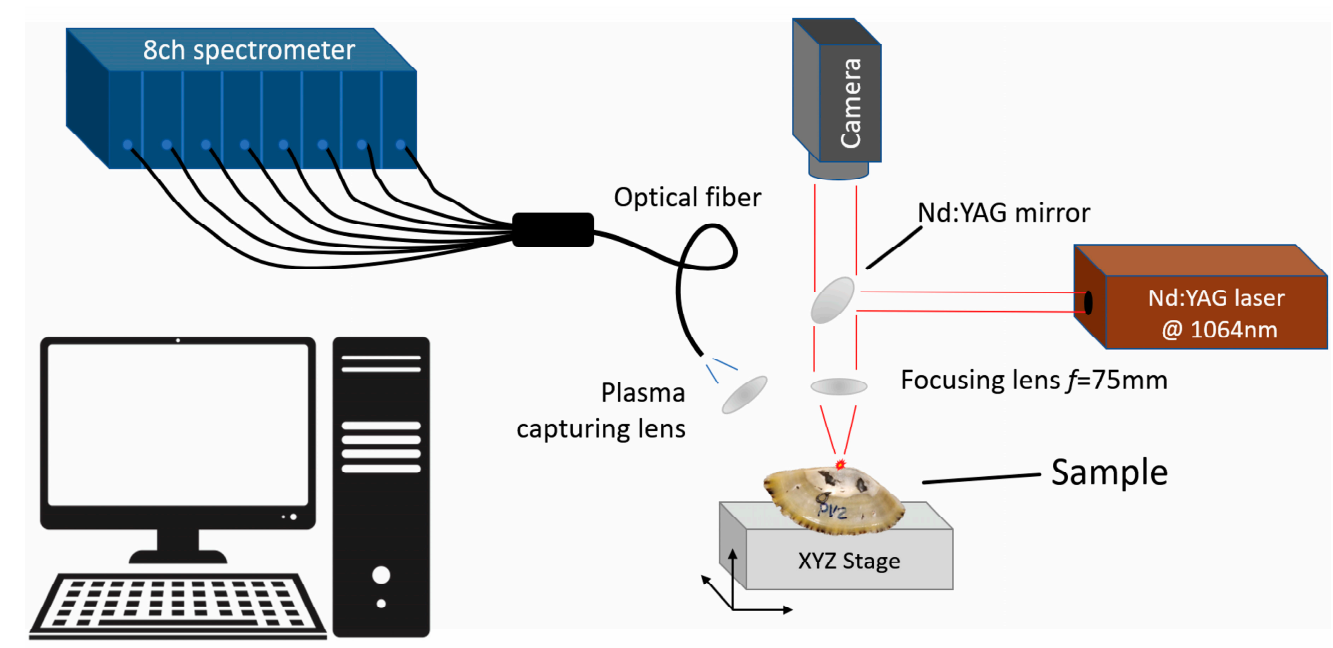

Figure 2. Laser-induced breakdown spectroscopy (LIBS) set-up.

\subsection{Shell Sample Preparation and $\mathrm{Mg} / \mathrm{Ca}$ Ratio Analysis}

Following the methodological procedures previously utilized in investigations conducted on Patella limpet species, shells were sectioned along the growth axis before being analyzed by LIBS $[57,69]$. The selected specimens were partially coated with a metal epoxy resin along maximum growth axis (i.e., from the anterior to the posterior margin) to avoid the shell breaking when sectioned (Figure 3a). Sectioning was performed using a Buehler Isomet low-speed saw and a diamond wheel at the IIIPC-University of Cantabria (Spain). Firstly, two thick sections ( $\sim 3 \mathrm{~mm}$ each) were obtained from each limpet, which were previously used for conducting the first sclerochronological analysis carried out on P. depressa species [72]. One out of the two remaining sections was used for the elemental analysis conducted here (Figure 3a). The remaining right hand limpet sections were ground on glass plates using 600 and $800 \mathrm{SiC}$ grit powder and polished with a $1 \mu \mathrm{m}$ diamond suspension grit until the internal growth lines and increments were clearly visible. According to the methodology previously applied to several limpet species $[39,57,65,69], \mathrm{Mg} / \mathrm{Ca}$ ratios were sequentially measured every $0.1 \mathrm{~mm}$ on the calcite layer equivalent to the $\mathrm{m}+2$ layer $[72,76]$ from the shell edge (i.e., the last portion of the shell growth) to the shell apex (i.e., the first portion of the shell growth) (Figure 3b). The measurement path from the edge was perpendicular to the growth lines and the diameter of the LIBS spot was always lower than $0.2 \mathrm{~mm}$. 
a)

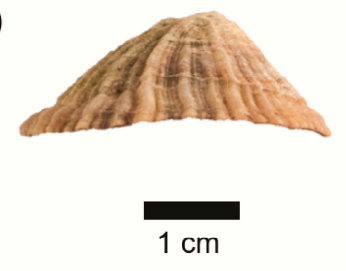

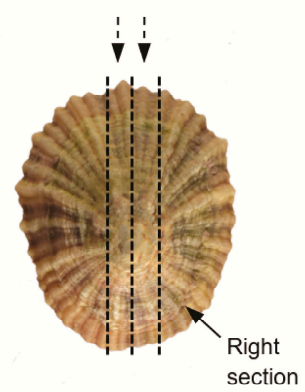

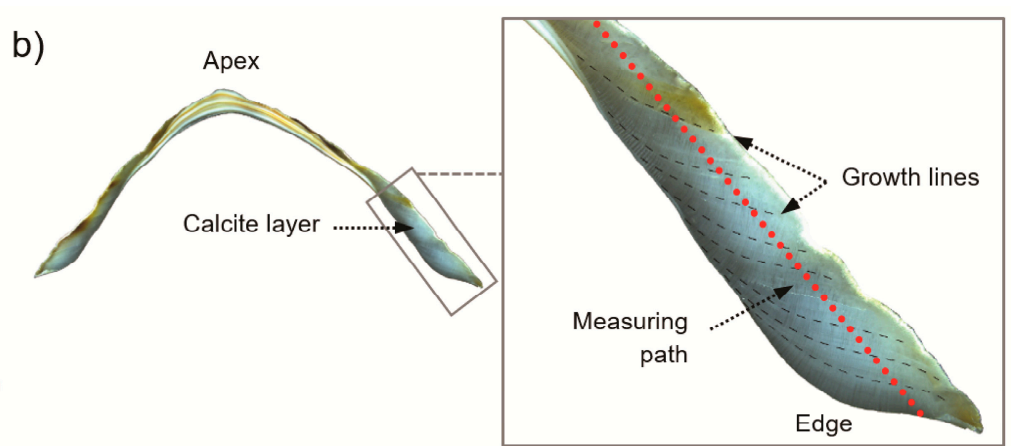

Figure 3. (a) Modern specimen of Patella depressa. Dashed lines indicate the cutting axis from which two thick sections were obtained. Dashed arrows show the two thick sections previously used for conducting a sclerochronological study on these shells. The remaining right-hand limpet section was used for elemental analyses carried out using LIBS. (b) Limpet cross-section showing the calcite layer and portion of the cross-section showing the visible growth lines. Red points indicate the LIBS measuring path.

\subsection{Elemental Spectra Processing and $\mathrm{Mg} / \mathrm{Ca}$ Ratio ( $\mathrm{mmol} / \mathrm{mol}$ ) Calculation}

In the recorded spectra, due to the high resolution and wide spectral range of the eight-channel spectrometer, many emission lines can be seen. Most of them are CaI and CaII lines, with several MgI and MgII lines and a few from SrI emission, in agreement with the expected chemical composition of mollusk shell carbonate. Although the presence of lithium in the carbonate of other species has been reported, no Li lines were found in our measurements. Due to the absence of specific matrix-matched calibration standards for marine mollusk shell biogenic carbonates, previous investigations carried out on marine mollusk shell biogenic carbonates obtained the $\mathrm{Mg} / \mathrm{Ca}$ values from the raw ratio of two elemental lines, expressed in arbitrary units $[57,58,68,69]$. In this study, a calibrationfree LIBS (CF-LIBS) technique was applied for the first time on biogenic carbonates in order to estimate molar concentrations of magnesium and calcium chemical elements. The algorithm used is an implementation of the method originally proposed by Ciucci et al. [71]. It obtains the concentrations from the Boltzmann and Saha-Boltzmann plots of many emission lines of the species of interest (in our case, CaI, CaII, MgI, and MgII) (Figure 4), and takes into account the electronic temperature and electron density of the plasma, thus reducing the variability of the signal due to shot-to-shot plasma fluctuations. To improve the accuracy of the results, the emission lines used by the CF algorithm have been carefully selected based on their signal to noise ratio in the spectra, energy levels, and self-absorption properties. One common issue of the CF-LIBS approach, in applications that use many measurements at different spatial points to create a sequence of concentrations, is that decisions to consider or discard specific emission lines are made individually for each spectrum. These decisions are dynamically made based on the particular signal to noise ratio of each emission peak, the quality of fit to a given peak function, or whether peak parameters are outliers in the Saha-Boltzmann plots or in the calculation of electron density. To reduce the variability of the concentrations determined across all the measurements of the sequences due to changes in the used emission lines, only the set of lines that were valid for all spatial points were considered here. This results in 16 lines of CaI, 5 of CaII and 6 of $\mathrm{MgI}$ being considered for the Saha-Boltzmann plots. As all MgII lines were discarded due to their high self-absorption, the concentration of ionized species was extrapolated using the Saha equilibrium equation [71]. The Matlab implementation of the CF-LIBS algorithm used in this work is openly available at github.com/acobo/CFLIBS. 


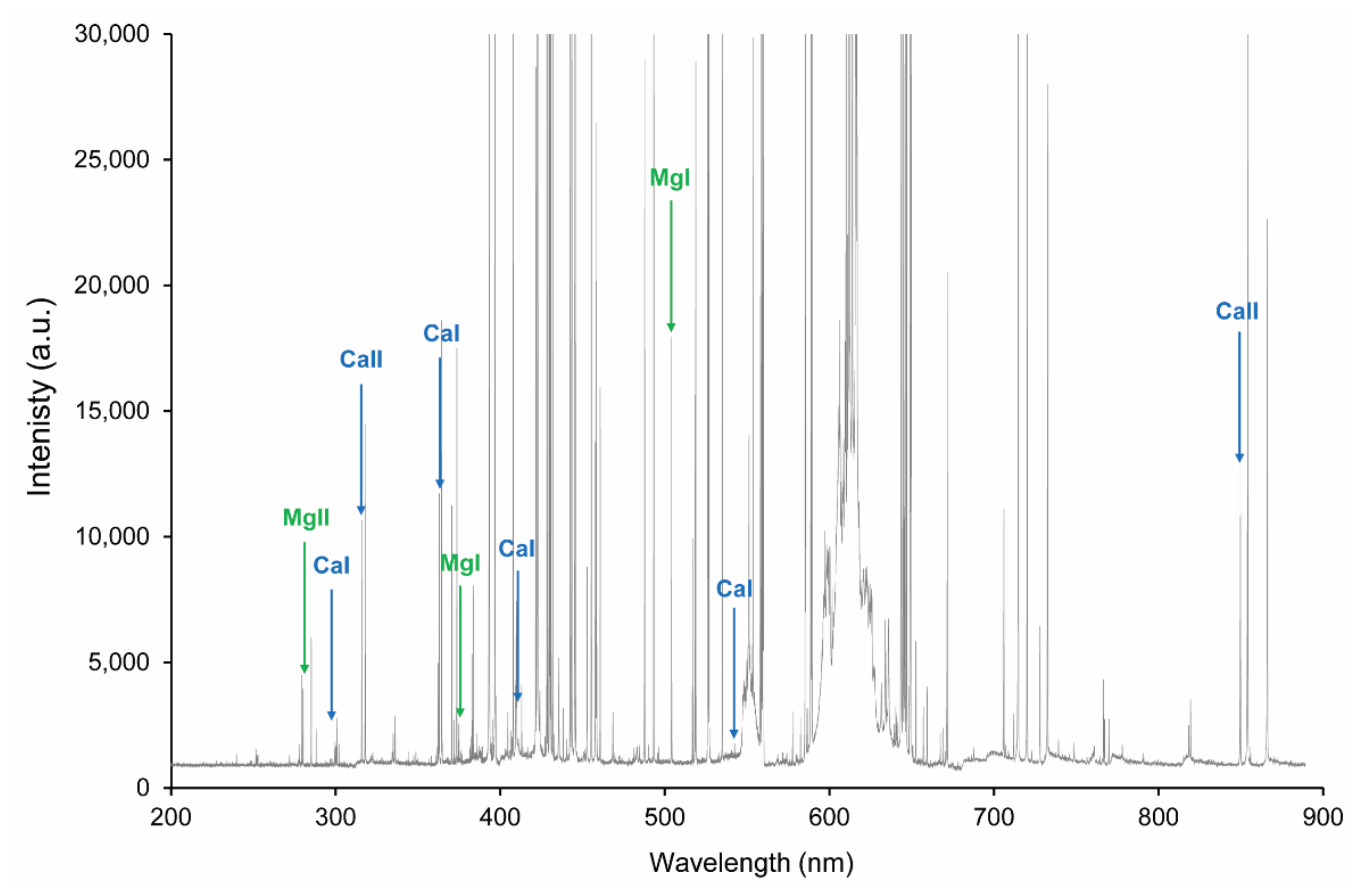

Figure 4. Sample spectrum showing some of the selected emission lines of MgI, MgII, CaI, and CaII used to estimate $\mathrm{Mg} / \mathrm{Ca}$ ratio values ( $\mathrm{mmol} / \mathrm{mol}$ ) through calibration-free (CF)-LIBS technique.

This procedure allowed us to obtain the relative concentration in $\mathrm{mmol} / \mathrm{mol}$ units and provided significant advantages to the line ratio approach, decreasing LIBS-derived variability caused by diverse experimental conditions (room temperature, optical alignment, or spectrometer configuration) between specimens, but also the variability found along a single cross-section of a limpet. In addition, to better assess the long-term (temperature related) ratio variations, the well-known singular spectrum analysis (SSA) was applied to the sequences $[77,78]$, a methodology that has already been applied on LIBS-derived series from marine mollusk shells elsewhere [57]. Each sequence was decomposed into 2 signal components and 6 noise components; the latter then being discarded. The effect of SSA is shown in Figure 5.

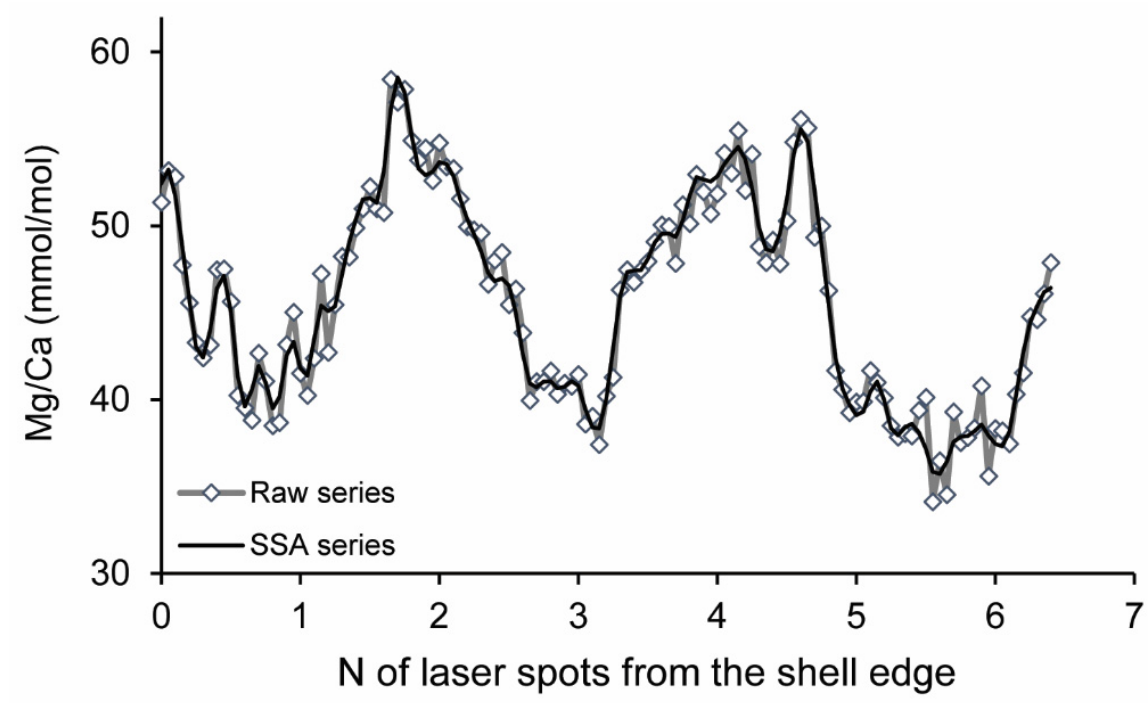

Figure 5. $\mathrm{Mg} /$ Ca ratios obtained with the proposed CF-LIBS procedure (grey line) and the same data postprocessed with the SSA algorithm (black line). 


\section{Results}

\subsection{Estimation of $\mathrm{Mg} / \mathrm{Ca}$ Ratio by CF-LIBS}

The elemental $\mathrm{Mg} / \mathrm{Ca}$ ratio was obtained on a predefined measurement path of the calcite layer for the four shells analyzed (Figure $3 b$ ). These ratio sequences are shown in Figure $6 \mathrm{a}-\mathrm{d}$. Values on the left-hand side correspond to the shell edge (date of collection) and values on the right-hand side correspond to the area close to the apex, i.e., earlier dates in the mollusk's lifespan.
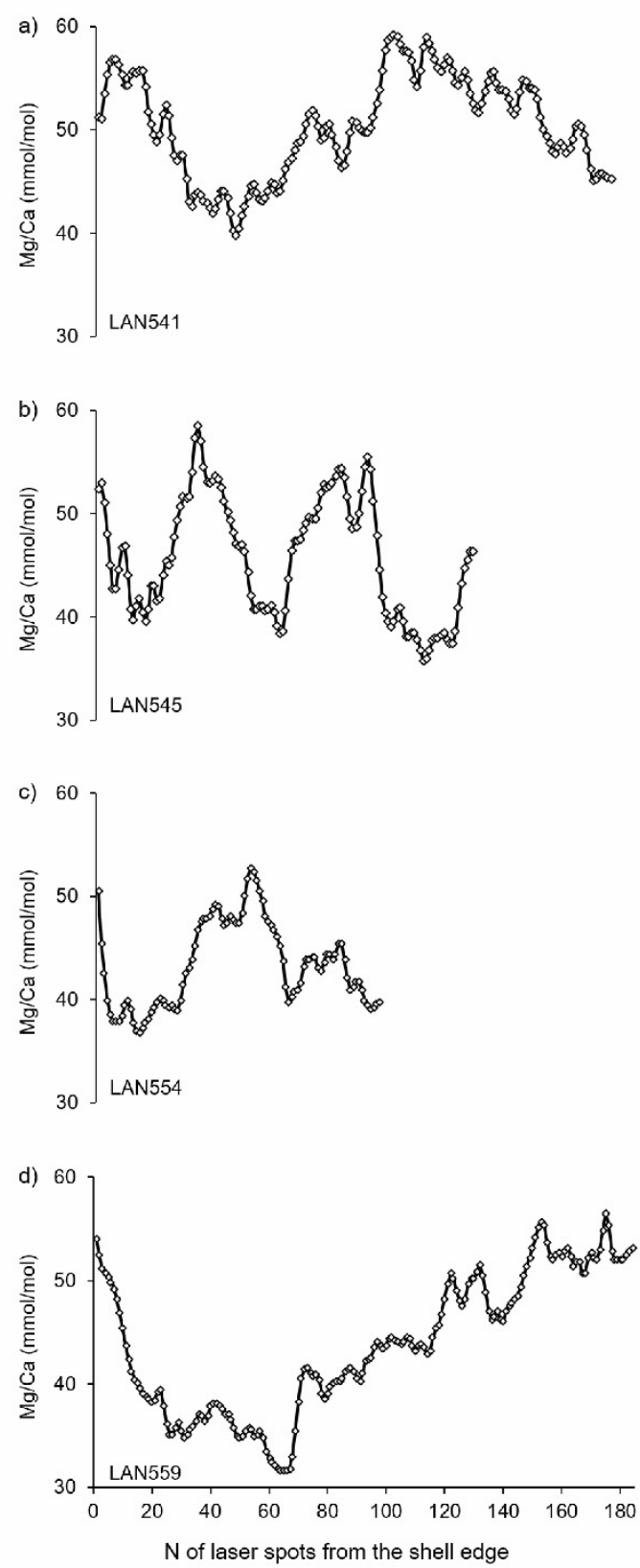

e) Calendar date
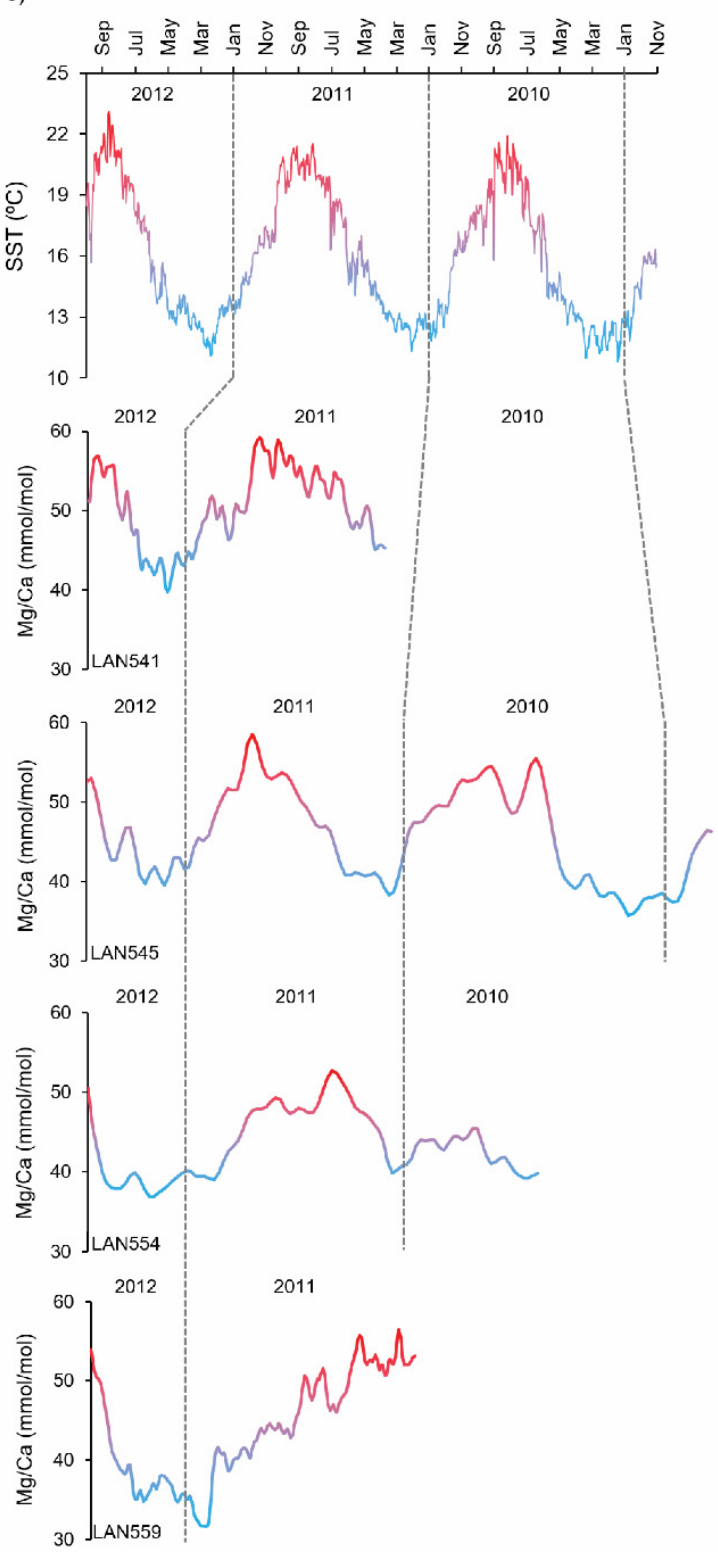

Figure 6. $\mathrm{Mg}$ /Ca ratio sequences obtained from (a) LAN541, (b) LAN545, (c) LAN554, and (d) LAN559. (e) Comparison between $\mathrm{Mg} / \mathrm{Ca}$ ratio sequences and instrumental SST ( $\left.T_{\text {meas }}\right)$. Red and blue colors indicate warm (i.e., summer) and cold (i.e., winter) temperatures, respectively.

The maximum and minimum $\mathrm{Mg} / \mathrm{Ca}$ ratio values (LAN541: 59.2 and $39.8 \mathrm{mmol} / \mathrm{mol}$, LAN545: 58.5 and $35.7 \mathrm{mmol} / \mathrm{mol}$, LAN554: 52.7 and $36.8 \mathrm{mmol} / \mathrm{mol}$, LAN559: 55.8, and $31.6 \mathrm{mmol} / \mathrm{mol}$ ) were relatively consistent between the four shells measured, although LAN554 and LAN559 reported a maximum and a minimum value lower than 
those derived from the other shells, respectively. Maximum $(59.2 \mathrm{mmol} / \mathrm{mol})$ and $\mathrm{min}-$ imum $(31.6 \mathrm{mmol} / \mathrm{mol}) \mathrm{Mg} / \mathrm{Ca}$ ratio values obtained herein were notably higher than elemental values previously measured on several calcite carbonate mollusk species using ICP-based techniques. Ferguson et al. [39] and Freitas et al. [56] obtained molar concentration values lower than $30 \mathrm{mmol} / \mathrm{mol}$ from modern limpets and scallops collected in the southern Iberian Peninsula. Likewise, Graniero et al. [65] and García-Escárzaga et al. [69] analyzed Patella vulgata limpets from Atlantic Europe, reporting elemental ratios (from ca. 10 to ca. $30 \mathrm{mmol} / \mathrm{mol}$ ) lower than obtained herein from P. depressa species by LIBS. We attribute this higher concentration of Mg measured by LIBS techniques to a possible species-dependent variability, but also to the CF-LIBS algorithm itself. The results could be affected by the self-absorption of Ca lines, as self-absorption tends to lead to an underestimation of the concentration of major elements in the chemical composition. The current implementation of the algorithm tries to reduce this effect with a careful selection of the emission lines, but the effect is difficult to remove entirely [79].

Another noticeable aspect of the sequences was their high variability, with apparent high-frequency fluctuations on top of the expected yearly sinusoidal variations. Although much research using the LIBS technique has tended to explain general intrinsic variability in LIBS spectra as a consequence of fluctuations in the varying plasma properties of each laser shot [80], we attribute this behavior to the actual composition heterogeneity of the biogenic carbonates on a micrometric scale, as has been suggested elsewhere $[58,61,69]$. As other studies report, the mineralization process in limpets may not only be dependent on seawater temperature, but also on other biological and environmental factors, such as mollusk ontogeny, intra-annual variation in shell growth rates, individual physiological processes, seawater salinity, and/or food supply conditions $[60,64,81,82]$. To evaluate the reliability of measured $\mathrm{Mg} / \mathrm{Ca}$ ratios, one limpet (LAN545) cross-section was measured twice along the same path. Although the ablated material was not strictly the same because the second series was measured on material located 20 micrometers deeper than the first series, a high correlation between the two series was expected. In this case, the results obtained were not processed using the SSA algorithm in order to compare actual raw $\mathrm{Mg} / \mathrm{Ca}$ ratio series. As can be seen in Figure 7, the two LAN545 series measured under the same experimental conditions showed the same trend through time, reporting a high correlation $\left(R^{2}=0.78\right)$ between them. Overall, this indicates that, while patterns can be interpreted with confidence, some intrinsic variability is inherent in using the LIBS technique, as well as a local heterogeneity in $\mathrm{Mg}$ distribution that is not only related to temperature dependence $[58,61,69,70]$.

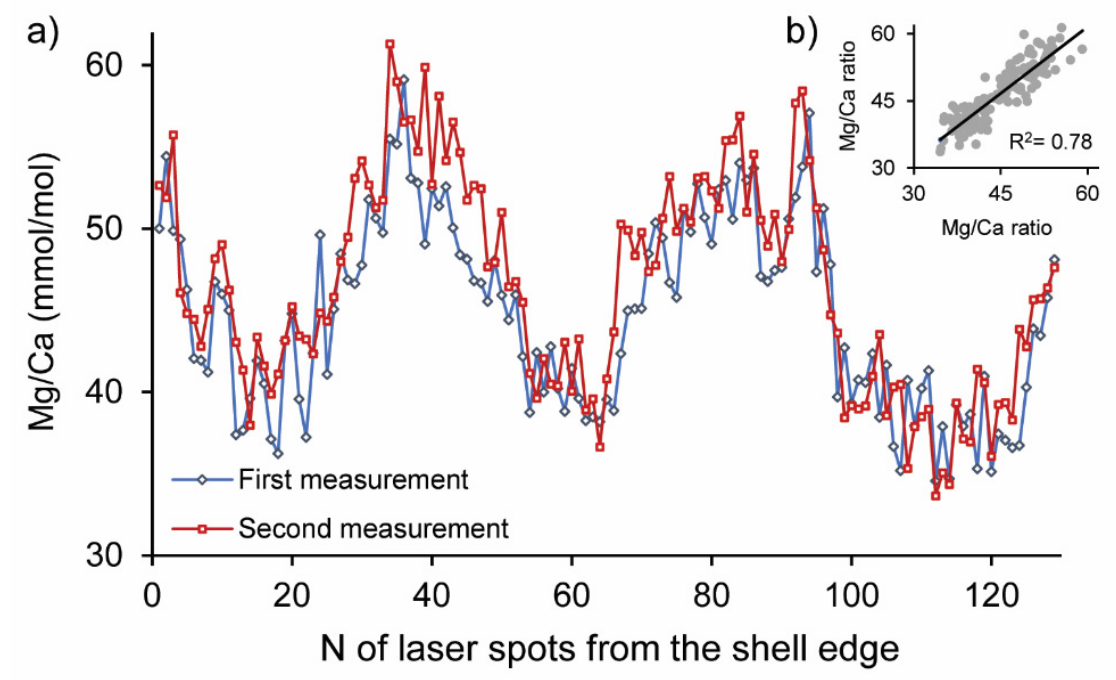

Figure 7. (a) Two $\mathrm{Mg} / \mathrm{Ca}$ ratio series obtained from a limpet cross-section measured on limpet LAN545 along the same path and (b) the correlation between both series. 


\section{2. $\mathrm{Mg} / \mathrm{Ca}$ Ratio Series vs $\delta^{18} \mathrm{O}_{\text {shell }}$ Profiles and Instrumental SST ( $\left.T_{\text {meas }}\right)$}

$\mathrm{The} \mathrm{Mg} / \mathrm{Ca}$ ratio series obtained showed very well-defined temporal patterns, covering a variable number of seasonal cycles depending on the age of the shell (Figure $6 a-d)$. A cycle refers to that part of the series between one minimum or one maximum value and the next one. Each cycle is therefore composed of a maximum, a minimum, and a variable number of intermediate values. A variable number of cycles were documented for each specimen. LAN541, LAN554, and LAN559 exhibited elemental fluctuations corresponding to approximately one cycle, while LAN545 covered a time span longer than two cycles. The number of cycles reported by the elemental series for each limpet was very consistent with the actual number of years of the life-span of these specimens, which was previously decoded through a detailed sclerochronological investigation carried out on these four same specimens combining a stable oxygen isotope analysis and a study of the growth patterns on every shell [72].

According to the results obtained from the previous trace element investigations carried out on biogenic carbonates [56,68], and especially those conducted on limpet species $[39,57,58,69]$, higher and lower $\mathrm{Mg} / \mathrm{Ca}$ ratio values represent warmer and colder SST, respectively, and each cycle corresponds to a complete year. This approach was also confirmed by the results derived from the sclerochronological study conducted on these four shells [72], since the cross-section areas where the minima and maxima $\mathrm{Mg} / \mathrm{Ca}$ ratio values were located coincided very well with those limpet portions deposited when coldest and warmest seawater temperatures were reached, respectively. A comparison between the obtained $\mathrm{Mg} / \mathrm{Ca}$ ratio series and instrumentally measured SST ( $T_{\text {meas }}$ ) at the place where the mollusks grew (Figure 6e) demonstrated a strong agreement between the two datasets through time, covering the expected number of summer and winter seasons through each mollusk's lifespan. Finally, the $\mathrm{Mg} / \mathrm{Ca}$ ratio series obtained herein were also compared with $\delta^{18} \mathrm{O}_{\text {shell }}$ values previously published for these same specimens [72]. The results reported a very high correlation between both profiles $\left(R^{2}=0.78-0.87\right)$ (Figure 8). Therefore, LIBS-derived $\mathrm{Mg} / \mathrm{Ca}$ ratio series from $P$. depressa clearly reported SST variations during the lifespan of the mollusk, covering a variable time span between one year (LAN559, Figure 6d) and almost three annual cycles (LAN545, Figure 6b).

In order to quantify the seawater temperature dependence of $\mathrm{Mg}$ incorporation into the carbonate matrix, maxima, minima, and average $\mathrm{Mg} / \mathrm{Ca}$ ratios obtained for each annual cycle, and maxima, minima and average $T_{\text {meas }}$ for each year were compared. Linear regression analysis showed very high correlations in each of the four shells $\left(R^{2}=0.91-0.95\right)$ (Figure 9a), even when all four shells were considered together in the same analysis $\left(R^{2}=0.86\right)$ (Figure $\left.9 b\right)$. Results obtained herein, therefore, for the first time, show that the $P$. depressa mollusk species incorporates magnesium into its calcium carbonate matrix in dependence with SST in northern Spain. Furthermore, the LIBS-derived Mg/Ca ratio series have enough resolution to correctly reflect the general evolution of SST variations on a year-round basis, with clearly distinguishable warmer and colder periods. This has implications for both paleoclimate reconstruction as well as for archaeological studies looking to determine seasonal collection strategies of this mollusk.

\subsection{Sea Surface Temperature Reconstruction and Paleoclimate Implications}

Reconstructing environmental conditions and climate change during the past, particularly at a seasonal resolution, is key for better understanding the impact of external changes on different aspects of human behavior $[4,5,14]$. Previous sclerochronological studies carried out on mollusks collected from northern Spain have revealed that $\delta^{18} \mathrm{O}_{\text {shell }}$ values obtained from Phorcus lineatus [51,73], P. vulgata [74], P. depressa [72], and Mytilus galloprovincialis [83] can all be considered as effective high-resolution SST recorders. However, to reconstruct SST from $\delta^{18} \mathrm{O}_{\text {shell }}$ values, information about $\delta^{18} \mathrm{O}_{\mathrm{sw}}$ is also required, the value of which is effectively unknown for the past. Different methodological approaches have been applied in order to overcome this limitation using, for example, the current $\delta^{18} \mathrm{O}_{\mathrm{sw}}$ for SST reconstruction during the Roman period [42], or even the Early Holocene 
period [84]; deciphering $\delta^{18} \mathrm{O}_{\mathrm{sw}}$ from available salinity datasets [41,85]; or correcting the current $\delta^{18} \mathrm{O}_{\mathrm{sw}}$ according to known prehistoric sea level changes [86].
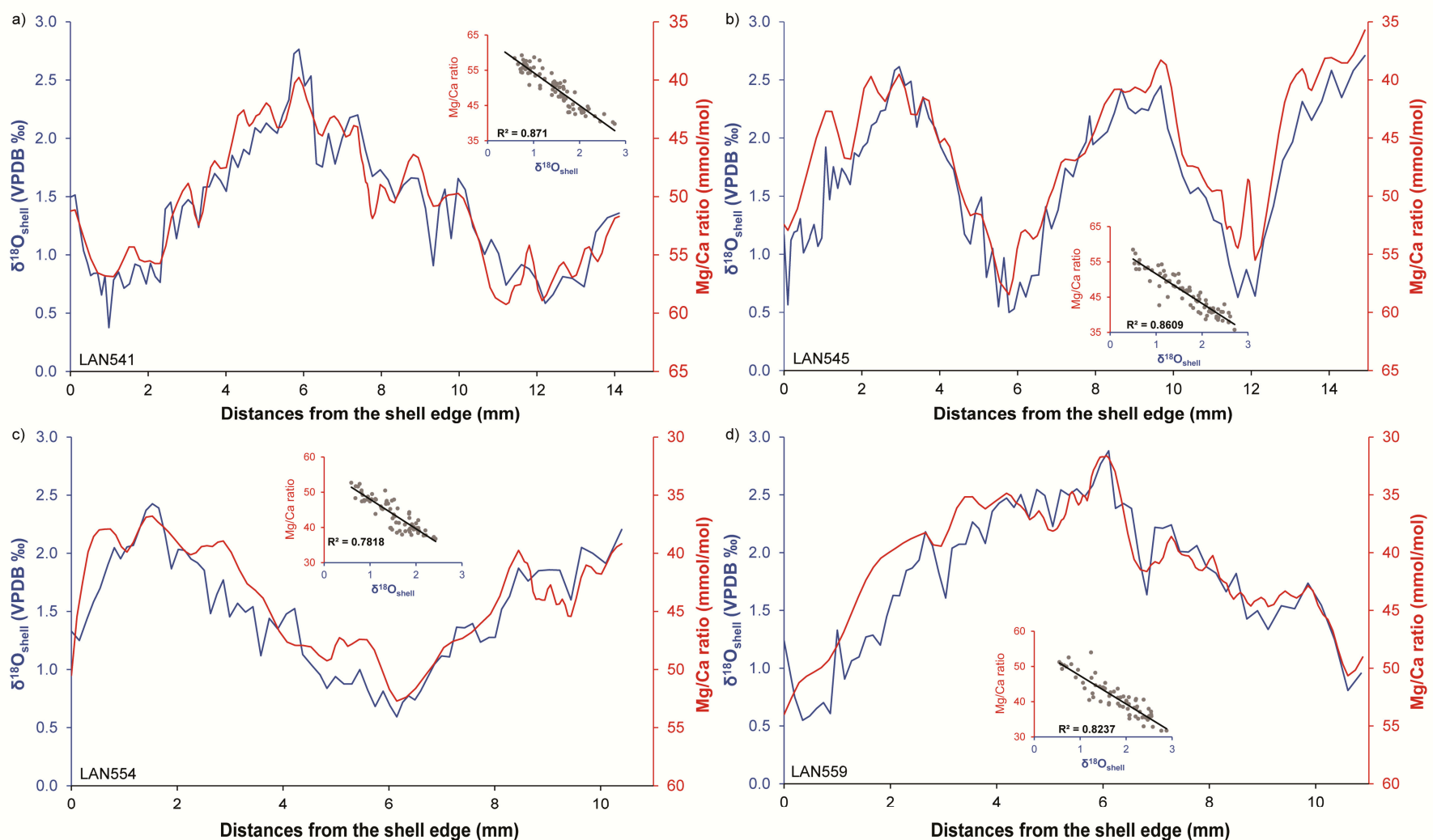

Figure 8. $\mathrm{Mg} / \mathrm{Ca}$ ratio and $\delta^{18} \mathrm{O}_{\text {shell }}$ series obtained from (a) LAN541, (b) LAN545, (c) LAN554, and (d) LAN559. LIBS derived $\mathrm{Mg} / \mathrm{Ca}$ ratios were aligned with $\delta^{18} \mathrm{O}_{\text {shell }}$ series according to major growth lines observed through limpet crosssections (Figure $3 \mathrm{~b}$ ) and the sclerochronological investigation previously conducted on these same specimens [72].

To try and overcome this issue, $\mathrm{Mg} / \mathrm{Ca}$ ratio analysis has been proposed as a reliable proxy independent of $\delta^{18} \mathrm{O}_{\mathrm{sw}}$ variations $[39,56,68]$. However, very few studies have reported a robust dependence between $\mathrm{Mg} / \mathrm{Ca}$ values and seawater temperatures when carbonate was deposited by the mollusks, and not every species appears to precipitate $\mathrm{Mg}$ in equilibrium with environmental surroundings, while the nonquantified effects of other biological and/or environment factors add further dimensions of uncertainty [58-61,64,65,81]. Therefore, more analyses involving new shell taxa and species collected from coastal areas that were previously not considered are required to better understand trace element precipitation mechanisms. During the last few years, LIBS has emerged as an optimal technique for rapidly investigating if trace element ratios measured on different mollusk species can be used as a climate proxy $[57,68,69]$. Nevertheless, previous investigations also noticed some limitations of LIBS. These studies showed differences in the $\mathrm{Mg} / \mathrm{Ca}$ ratio values (from emission line ratios) obtained between specimens, which were caused by inconsistent LIBS experimental conditions and precluded the development of an equation for estimating SST from $\mathrm{Mg} / \mathrm{Ca}$ values [69]. Here, the LIBS-derived variability was reduced using the CF-LIBS technique, resulting in very similar regression lines between each measured specimen of $P$. depressa (Figure 9a). This allowed us to tentatively develop the first equation to estimate SST from LIBS-derived $\mathrm{Mg} / \mathrm{Ca}$ ratios $\left(\mathrm{T}_{\mathrm{Mg} / \mathrm{Ca}}\right)$ considering all maxima, minima, and average values derived from the four shells (Figure $9 b$ ):

$$
\mathrm{T}_{\mathrm{Mg} / \mathrm{Ca}}=0.5492 \times \mathrm{Mg} / \text { Ca ratio value }-8.5532
$$


Nevertheless, further investigation, increasing the number of shells analyzed and improving the CF-LIBS technique algorithm, is still required in order to obtain a more accurate equation.
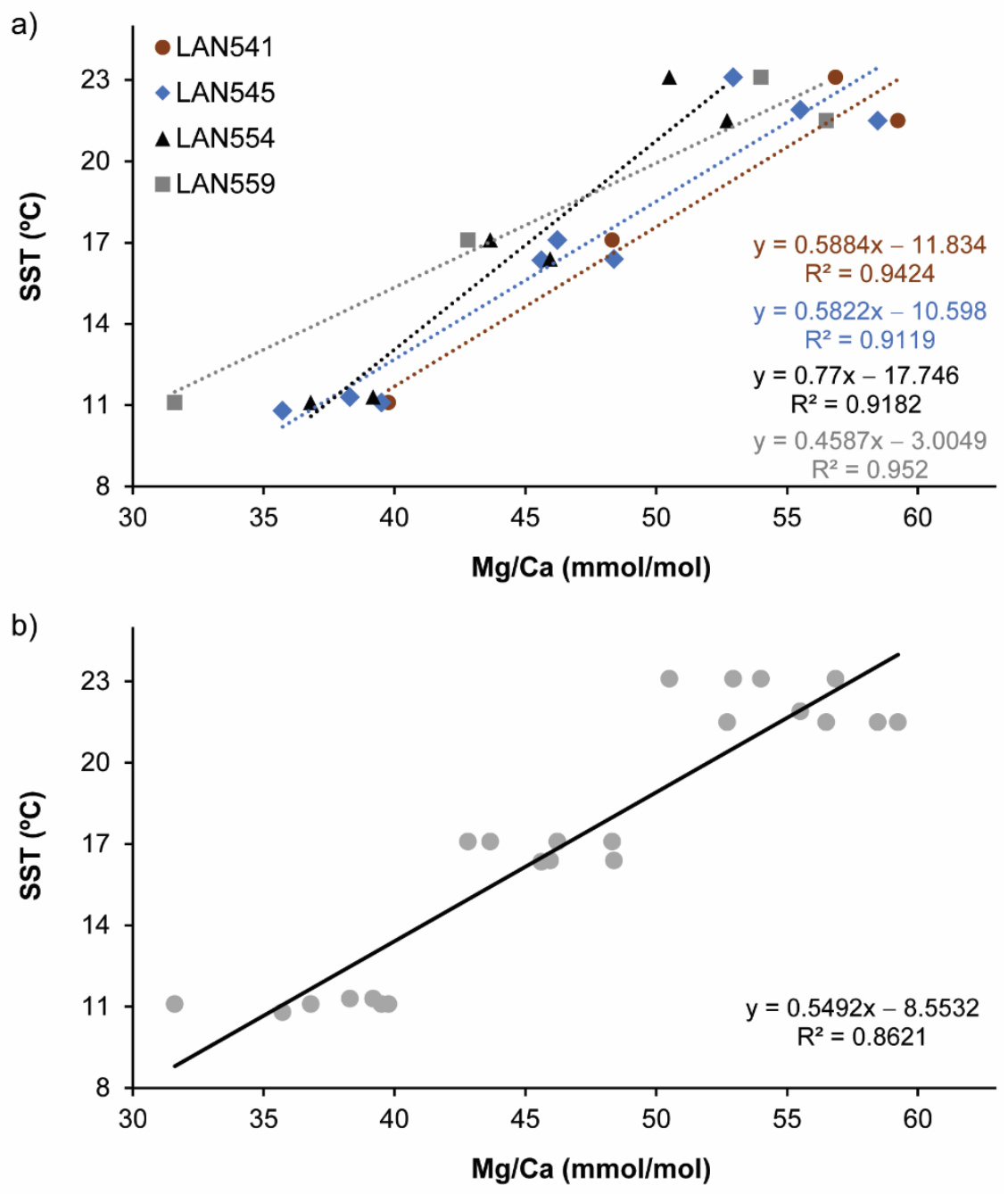

Figure 9. (a) Measured minimum, average, and maximum $\mathrm{Mg} / \mathrm{Ca}$ ratios for each specimen in relation to the minimum, average, and maximum of instrumentally measured seawater temperature. Regression lines and equations, and the correlations, were calculated individually for each sample. (b) Measured minimum, average, and maximum $\mathrm{Mg} / \mathrm{Ca}$ ratios for all specimens in relation to the minimum, average, and maximum of instrumental seawater temperature. The regression lines and equations, and the correlation, were calculated from values obtained from the four samples together.

\subsection{P. depressa Season of Collection and Archaeological Implications}

Beyond paleoclimate conditions, determining the season in which archaeological mollusks were collected by prehistoric foragers also has significant implications for better understanding past subsistence strategies, as well as providing valuable information relating to the seasonality of site occupation and mobility patterns of past societies $[46,87-89]$. The LIBS technique can offer key valuable advantages for future studies. Not only does LIBS avoid sample pretreatments, but it also avoids highly time-consuming sampling procedures in order to extract carbonate powders along the axes of shell growth $[50,74,90,91]$. García-Escárzaga et al. [69] showed that it offers a $20 \times$ reduction in the time required to measure a specimen, with respect to traditional ICP-based methodologies. In addition, the LIBS technique also offers a notable cost reduction relative to isotope ratio mass spectrometry techniques. The time and cost reductions enable a notable increase in the number of specimens analyzed for each stratigraphic unit, offering more statistically consistent results 
through time and between sites. Moreover, as can be seen from the data present here, and in other studies, the ability of $\mathrm{Mg} / \mathrm{Ca}$ ratio series to decipher past climate changes on an intra-annual basis means that the approach is able to reveal seasonality in mollusk collection patterns $[57,58,69]$.

To decipher the season of collection of each specimen, the most recent (youngest) calcium carbonate deposited by the mollusk, as well as the sequence trend prior to the mollusk's death, were employed [44,47,87]. $\mathrm{Mg} / \mathrm{Ca}$ ratio values representative of the last mollusk growth in the four shells always reported a value higher than $50 \mathrm{mmol} / \mathrm{mol}$. However, slight differences were observed in the series trend during the weeks or months prior to the collection event. While LAN541 showed a harvest event during a period of cooling SST, just after the annual SST maximum was reached, LAN545, LAN554, and LAN559 reported a collection event during a warming trend in SST, just before reaching the maximum value documented during the previous annual cycle. Only LAN559 reported a final value $(54 \mathrm{mmol} / \mathrm{mol})$ similar to the maximum observed during the previous summer $(56.5 \mathrm{mmol} / \mathrm{mol})$, which suggests a collection near the warmest annual SST. The sclerochronological study previously carried out on these same four shells revealed that LAN545 and LAN554 specimens stopped their growth for one and two months, respectively, in summer 2012. Both specimens resumed carbonate deposition at the end of September 2012, just before the collection event [72]. This explains why LAN545 and LAN554 did not record the annual maximum SST. In spite of these growth stoppages in LAN545 and LAN554, the last Mg/Ca ratio value of both specimens was always located in the upper quartile of the total annual range reported from each individual $[44,87,92]$, which corresponded to the summer season.

Overall, if the real collection date of these specimens (i.e., end of summer) were unknown, the series obtained would have allowed us to decipher, with a high temporal resolution, the period of the collection in the case of LAN541 and LAN559, which clearly reported a collection during the end of the warmer season. Although LAN545 and LAN554 did not reach the annual maximum SST, the $\mathrm{Mg}$ /Ca ratio series also correctly suggested the general season of collection (i.e., summer). As also occurred with the isotopic series obtained from these same two specimens (LAN545 and LAN554) [72], a collection at the end of summer could have also been correctly deduced if $\mathrm{Mg} / \mathrm{Ca}$ ratio series were combined with growth line analyses in order to take into account possible growth stoppages close to the edge. In summary, our results highlight that the season of collection for $P$. depressa can be accurately, rapidly, and inexpensively determined using LIBS-derived $\mathrm{Mg} / \mathrm{Ca}$ ratio series and multiproxy sclerochronological investigations, combining trace element analyses and incremental shell growth patterns. The LIBS technique, therefore, offers a significant opportunity to effectively increase the number of shells measured for each archaeological context, obtaining thus more accurate archaeological conclusions.

\section{Conclusions}

For the first time, we applied the CF-LIBS technique to biogenic calcium carbonate to estimate molar concentrations of chemical elements. Our results reported slight differences with molar concentration data derived from ICP-based methodologies, suggesting that algorithms developed to conduct CF-LIBS must be improved in further studies, particularly, to deal with the self-absorption effect that tends to overestimate the concentration of minority elements. Nevertheless, $\mathrm{Mg} / \mathrm{Ca}$ ratio sequences derived from $P$. depress $a$ using this novel LIBS technique correctly reflected annual variations in SST, demonstrating that $P$. depressa incorporates magnesium into its calcium carbonate matrix in dependence with SST in northern Spain. The high correlation between $\mathrm{Mg} / \mathrm{Ca}$ series and SST at the place where the mollusks grew allowed us to obtain a tentative equation to estimate SST from measured $\mathrm{Mg} / \mathrm{Ca}$ ratios, although further studies are still required utilizing more samples and improving the CF-LIBS algorithm. Together then, this novel methodology represents a valuable approach for paleoclimate applications in the region, as well as a means of 
estimating of the season when mollusks from archaeological sites were collected by past humans with implications for the study of human-environment interactions.

Author Contributions: I.G.-Z. collected the mollusk shells analyzed herein. A.G.-E. cut and polished the limpet cross-sections. A.G.-E. and M.M.-M. performed the measurements by LIBS. A.C. developed and applied the CF-LIBS technique to estimate the molar concentrations of magnesium and calcium. All authors (A.G.-E., M.M.-M., A.C., I.G.-Z., A.A. and P.R.) interpreted the data. All authors (A.G.-E., M.M.-M., A.C., I.G.-Z., A.A. and P.R.) wrote and provided comments on the manuscript. All authors have read and agreed to the published version of the manuscript.

Funding: This research was performed as part of the projects HAR2016-75605-R, HAR2017-86262$\mathrm{P}$ and PID2019-107270RB-C21/AEI/10.13039/501100011033, funded by the Spanish Ministry of Economy and Competitiveness, MINECO. During the development of this research A.G.E was funded by the Basque Country Postdoctoral Program through a postdoctoral grant (POS_2020_2_0032). This study has also been supported by the Prehistoric Research Consolidated Group of the Basque Country University (IT-1223-19), funded by the Basque Country Government. P.R. is funded by the Max Planck Society.

Institutional Review Board Statement: This investigation does not involve research on animals transgenic small laboratory animals, animals transgenic farm animals, non-human primates or animals cloned farm animals. During the development of this study modern mollusc specimens were collected monthly over the course of one complete year. The required authorizations were obtained from Fishing Activity Service of the Cantabrian Government. The study was conducted according to the guidelines of the Declaration of Helsinki, and approved by the Institutional Review Board (or Ethics Committee) of Fishing Activity Service of the Cantabrian Government.

Informed Consent Statement: Not applicable.

Data Availability Statement: All of the data reported in the paper are presented in the main text. All $\mathrm{Mg} / \mathrm{Ca}$ ratio values obtained were included in the Figures 5-7. Sea surface temperatures (SST) at the place where the mollusks grew were previously published [51,72-74]. Stable oxygen isotope values used to construct Figure 8 were previously published [72]. The mollusk shells analyzed in this investigation are curated in the Archaeology collection at the University of Cantabria (Santander, Spain). The Matlab implementation of the CF-LIBS algorithm used in this work is openly available at github.com/acobo/CFLIBS.

Acknowledgments: We thank the Max Planck Society, University of the Basque Country (UPV/EHU), Grupo de Ingeniería Fotónica (GIF), and University of Cantabria (UC) for support. We are grateful to José Miguel López-Higuera (GIF) for their scientific support.

Conflicts of Interest: The authors declare no conflict of interest.

\section{References}

1. Meggers, B.J. Climatic oscillation as a factor in the prehistory of Amazonia. Am. Antiq. 1979, 44, 252-266. [CrossRef]

2. Berglund, B.E. Human impact and climate changes-Synchronous events and a causal link? Quat. Int. 2003, 105, 7-12. [CrossRef]

3. Willcox, G.; Buxo, R.; Herveux, L. Late Pleistocene and early Holocene climate and the beginnings of cultivation in northern Syria. Holocene 2009, 19, 151-158. [CrossRef]

4. Roberts, P.; Stewart, M.; Alagaili, A.N.; Breeze, P.; Candy, I.; Drake, N.; Groucutt, H.S.; Scerri, E.M.L.; Lee-Thorp, J.; Louys, J.; et al. Fossil herbivore stable isotopes reveal middle Pleistocene hominin palaeoenvironment in 'Green Arabia'. Nat. Ecol. Evol. 2018, 2, 1871-1878. [CrossRef] [PubMed]

5. Burke, A.; Riel-Salvatore, J.; Barton, C.M. Human response to habitat suitability during the Last Glacial Maximum in Western Europe. J. Quat. Sci. 2018, 33, 335-345. [CrossRef]

6. Gosling, S.N.; Arnell, N.W. A global assessment of the impact of climate change on water scarcity. Clim. Chang. 2016, 134, 371-385. [CrossRef]

7. Pecl, G.T.; Araújo, M.B.; Bell, J.D.; Blanchard, J.; Bonebrake, T.C.; Chen, I.-C.; Clark, T.D.; Colwell, R.K.; Danielsen, F.; Evengård, B.; et al. Biodiversity redistribution under climate change: Impacts on ecosystems and human well-being. Science 2017, 355, eaai9214. [CrossRef]

8. Gilligan, I. Neanderthal extinction and modern human behaviour: The role of climate change and clothing. World Archaeol. 2007, 39, 499-514. [CrossRef]

9. Staubwasser, M.; Drăgușin, V.; Onac, B.P.; Assonov, S.; Ersek, V.; Hoffmann, D.L.; Veres, D. Impact of climate change on the transition of Neanderthals to modern humans in Europe. Proc. Natl. Acad. Sci. USA 2018, 115, 9116. [CrossRef] 
10. Defleur, A.R.; Desclaux, E. Impact of the last interglacial climate change on ecosystems and Neanderthals behavior at Baume Moula-Guercy, Ardèche, France. J. Archaeol. Sci. 2019, 104, 114-124. [CrossRef]

11. Rosen, A.M.; Rivera-Collazo, I. Climate change, adaptive cycles, and the persistence of foraging economies during the late Pleistocene/Holocene transition in the Levant. Proc. Natl. Acad. Sci. USA 2012, 109, 3640-3645. [CrossRef] [PubMed]

12. Fernández-López de Pablo, J.; Gutiérrez-Roig, M.; Gómez-Puche, M.; McLaughlin, R.; Silva, F.; Lozano, S. Palaeodemographic modelling supports a population bottleneck during the Pleistocene-Holocene transition in Iberia. Nat. Commun. 2019, 10, 1872. [CrossRef]

13. Maier, A.; Stojakowits, P.; Mayr, C.; Pfeifer, S.; Preusser, F.; Zolitschka, B.; Anghelinu, M.; Bobak, D.; Duprat-Oualid, F.; Einwögerer, T.; et al. Cultural evolution and environmental change in Central Europe between 40 and $15 \mathrm{ka}$. Quat. Int. 2020. [CrossRef]

14. Roffet-Salque, M.; Marciniak, A.; Valdes, P.J.; Pawłowska, K.; Pyzel, J.; Czerniak, L.; Krüger, M.; Roberts, C.N.; Pitter, S.; Evershed, R.P. Evidence for the impact of the 8.2-kyBP climate event on Near Eastern early farmers. Proc. Natl. Acad. Sci. USA 2018, 115, 8705-8709. [CrossRef]

15. Betti, L.; Beyer, R.M.; Jones, E.R.; Eriksson, A.; Tassi, F.; Siska, V.; Leonardi, M.; Maisano Delser, P.; Bentley, L.K.; Nigst, P.R.; et al. Climate shaped how Neolithic farmers and European hunter-gatherers interacted after a major slowdown from 6100 bce to 4500 bce. Nat. Hum. Behav. 2020, 4, 1004-1010. [CrossRef] [PubMed]

16. Thomas, K.D. Molluscs emergent, Part I: Themes and trends in the scientific investigation of mollusc shells as resources for archaeological research. J. Archaeol. Sci. 2015, 56, 133-140. [CrossRef]

17. Wong, C.I.; Breecker, D.O. Advancements in the use of speleothems as climate archives. Quat. Sci. Rev. 2015, 127, 1-18. [CrossRef]

18. Pederzani, S.; Britton, K. Oxygen isotopes in bioarchaeology: Principles and applications, challenges and opportunities. Earth Sci. Rev. 2019, 188, 77-107. [CrossRef]

19. Moberg, A.; Sonechkin, D.M.; Holmgren, K.; Datsenko, N.M.; Karlén, W. Highly variable Northern Hemisphere temperatures reconstructed from low- and high-resolution proxy data. Nature 2005, 433, 613-617. [CrossRef]

20. Andrus, C.F.T. Shell midden sclerochronology. Quat. Sci. Rev. 2011, 30, 2892-2905. [CrossRef]

21. Marean, C.W.; Bar-Matthews, M.; Bernatchez, J.; Fisher, E.; Goldberg, P.; Herries, A.I.R.; Jacobs, Z.; Jerardino, A.; Karkanas, P.; Minichillo, T.; et al. Early human use of marine resources and pigment in South Africa during the Middle Pleistocene. Nature 2007, 449, 905-908. [CrossRef]

22. Cortés-Sánchez, M.; Morales-Muñiz, A.; Simón-Vallejo, M.D.; Lozano-Francisco, M.C.; Vera-Peláez, J.L.; Finlayson, C.; RodríguezVidal, J.; Delgado-Huertas, A.; Jiménez-Espejo, F.J.; Martínez-Ruiz, F.; et al. Earliest Known Use of Marine Resources by Neanderthals. PLoS ONE 2011, 6, e24026. [CrossRef] [PubMed]

23. Ramos-Muñoz, J.; Cantillo-Duarte, J.J.; Bernal-Casasola, D.; Barrena-Tocino, A.; Domínguez-Bella, S.; Vijande-Vila, E.; ClementeConte, I.; Gutiérrez-Zugasti, I.; Soriguer-Escofet, M.; Almisas-Cruz, S. Early use of marine resources by Middle/Upper Pleistocene human societies: The case of Benzú rockshelter (northern Africa). Quat. Int. 2016, 407, 6-15. [CrossRef]

24. Erlandson, J.M. The archaeology of aquatic adaptations: Paradigms for a new millennium. J. Archaeol. Res. 2001, 9, 287-350. [CrossRef]

25. Bicho, N.; Umbelino, C.; Detry, C.; Pereira, T. The emergence of Muge Mesolithic shell middens in central Portugal and the 8200 cal yr BP cold event. J. Isl. Coast. Archaeol. 2010, 5, 86-104. [CrossRef]

26. Colonese, A.C.; Mannino, M.A.; Bar-Yosef Mayer, D.E.; Fa, D.A.; Finlayson, J.C.; Lubell, D.; Stiner, M.C. Marine mollusc exploitation in Mediterranean prehistory: An overview. Quat. Int. 2011, 239, 86-103. [CrossRef]

27. Álvarez-Fernández, E. Humans and marine resource interaction reappraised: Archaeofauna remains during the late Pleistocene and Holocene in Cantabrian Spain. J. Anthropol. Archaeol. 2011, 30, 327-343. [CrossRef]

28. Zilhão, J.; Angelucci, D.E.; Badal-García, E.; d’Errico, F.; Daniel, F.; Dayet, L.; Douka, K.; Higham, T.F.G.; Martínez-Sánchez, M.J.; Montes-Bernárdez, R.; et al. Symbolic use of marine shells and mineral pigments by Iberian Neandertals. Proc. Natl. Acad. Sci. USA 2010, 107, 1023-1028. [CrossRef]

29. Cuenca-Solana, D. The use of shells by hunter-fisher-gatherers and farmers from the early upper Palaeolithic to the Neolithic in the European Atlantic façade: A technological perspective. J. Isl. Coast. Archaeol. 2015, 10, 52-75. [CrossRef]

30. Rigaud, S.; Gutiérrez-Zugasti, I. Symbolism among the last hunter-fisher-gatherers in northern Iberia: Personal ornaments from El Mazo and El Toral III Mesolithic shell midden sites. Quat. Int. 2016, 407Pt B, 131-144. [CrossRef]

31. Branscombe, T.L.; Bosch, M.D.; Miracle, P.T. Seasonal Shellfishing across the East Adriatic Mesolithic-Neolithic Transition: Oxygen Isotope Analysis of Phorcus turbinatus from Vela Spila (Croatia). Environ. Archaeol. 2020, 1-14. [CrossRef]

32. Álvarez, M.; Briz Godino, I.; Balbo, A.; Madella, M. Shell middens as archives of past environments, human dispersal and specialized resource management. Quat. Int. 2011, 239, 1-7. [CrossRef]

33. Crisp, D. The effects of the severe winter of 1962-63 on marine life in Britain. J. Anim. Ecol. 1964, 33, 165-210. [CrossRef]

34. Albano, P.G.; Steger, J.; Bošnjak, M.; Dunne, B.; Guifarro, Z.; Turapova, E.; Hua, Q.; Kaufman, D.S.; Rilov, G.; Zuschin, M. Native biodiversity collapse in the eastern Mediterranean. Proc. R. Soc. B Biol. Sci. 2021, 288. [CrossRef]

35. Gutiérrez-Zugasti, I.; Cuenca-Solana, D. Biostratigraphy of shells and climate changes in the Cantabrian region (northern Spain) during the Pleistocene-Holocene transition. In Archaeomalacology Shells in the Arcaheological Record. British Archaeological Reports International Series 2666; Szabó, K., Dupont, C., Dimitrijevic, V., Gómez-Castélum, L., Serrand, N., Eds.; Archaeopress: Oxford, UK, 2014; pp. 225-234. 
36. Álvarez-Fernández, E. Continuity of human-marine fauna interaction during the Holocene in Cantabrian Spain. Quat. Int. 2015, 364, 188-195. [CrossRef]

37. Mieszkowska, N.; Hawkins, S.; Burrows, M.; Kendall, M. Long-term changes in the geographic distribution and population structures of Osilinus lineatus (Gastropoda: Trochidae) in Britain and Ireland. J. Mar. Biol. Assoc. UK 2007, 87, 537-545. [CrossRef]

38. Kleisner, K.M.; Fogarty, M.J.; McGee, S.; Hare, J.A.; Moret, S.; Perretti, C.T.; Saba, V.S. Marine species distribution shifts on the U.S. Northeast Continental Shelf under continued ocean warming. Prog. Oceanogr. 2017, 153, 24-36. [CrossRef]

39. Ferguson, J.E.; Henderson, G.M.; Fa, D.A.; Finlayson, J.C.; Charnley, N.R. Increased seasonality in the Western Mediterranean during the last glacial from limpet shell geochemistry. Earth Planet. Sci. Lett. 2011, 308, 325-333. [CrossRef]

40. Leng, M.J.; Lewis, J.P. Oxygen isotopes in Molluscan shell: Applications in environmental archaeology. Environ. Archaeol. 2016, 21, 295-306. [CrossRef]

41. Wanamaker, A.D.; Kreutz, K.J.; Schöne, B.R.; Pettigrew, N.; Borns, H.W.; Introne, D.S.; Belknap, D.; Maasch, K.A.; Feindel, S. Coupled North Atlantic slope water forcing on Gulf of Maine temperatures over the past millennium. Clim. Dyn. 2008, 31, 183-194. [CrossRef]

42. Wang, T.; Surge, D.; Mithen, S. Seasonal temperature variability of the Neoglacial (3300-2500 BP) and Roman Warm Period (2500-1600 BP) reconstructed from oxygen isotope ratios of limpet shells (Patella vulgata), Northwest Scotland. Palaeogeogr. Palaeoclimatol. Palaeoecol. 2012, 317-318, 104-113. [CrossRef]

43. Flores, C.; Broitman, B.R. Nearshore paleoceanogaphic conditions through the holocene: Shell carbonate from archaeological sites of the atacama desert coast. Palaeogeogr. Palaeoclimatol. Palaeoecol. 2021, 562, 110090. [CrossRef]

44. Colonese, A.C.; Troelstra, S.; Ziveri, P.; Martini, F.; Lo Vetro, D.; Tommasini, S. Mesolithic shellfish exploitation in SW Italy: Seasonal evidence from the oxygen isotopic composition of Osilinus turbinatus shells. J. Archaeol. Sci. 2009, 36, 1935-1944. [CrossRef]

45. Mannino, M.A.; Thomas, K.D.; Leng, M.J.; Di Salvo, R.; Richards, M.P. Stuck to the shore? Investigating prehistoric huntergatherer subsistence, mobility and territoriality in a Mediterranean coastal landscape through isotope analyses on marine mollusc shell carbonates and human bone collagen. Quat. Int. 2011, 244, 88-104. [CrossRef]

46. Prendergast, A.L.; Stevens, R.E.; O'Connell, T.C.; Fadlalak, A.; Touati, M.; al-Mzeine, A.; Schöne, B.R.; Hunt, C.O.; Barker, G. Changing patterns of eastern Mediterranean shellfish exploitation in the Late Glacial and Early Holocene: Oxygen isotope evidence from gastropod in Epipaleolithic to Neolithic human occupation layers at the Haua Fteah cave, Libya. Quat. Int. 2016, 407, 80-93. [CrossRef]

47. García-Escárzaga, A.; Gutiérrez-Zugasti, I.; Cobo, A.; Cuenca-Solana, D.; Martín-Chivelet, J.; Roberts, P.; González-Morales, M.R. Stable oxygen isotope analysis of Phorcus lineatus (da Costa, 1778) as a proxy for foraging seasonality during the Mesolithic in northern Iberia. Archaeol. Anthropol. Sci. 2019, 11, 5631-5644. [CrossRef]

48. Wanamaker, A.D.; Kreutz, K.J.; Borns, H.W.; Introne, D.S.; Feindel, S.; Funder, S.; Rawson, P.D.; Barber, B.J. Experimental determination of salinity, temperature, growth, and metabolic effects on shell isotope chemistry of Mytilus edulis collected from Maine and Greenland. Paleoceanography 2007, 22. [CrossRef]

49. Owen, E.F.; Wanamaker Jr, A.D.; Feindel, S.C.; Schöne, B.R.; Rawson, P.D. Stable carbon and oxygen isotope fractionation in bivalve (Placopecten magellanicus) larval aragonite. Geochim. Cosmochim. Acta 2008, 72, 4687-4698. [CrossRef]

50. Surge, D.; Wang, T.; Gutierrez-Zugasti, I.; Kelley, P.H. Isotope sclerochronology and season of annual growth line formation in limpet shells (Patella vulgata) from cold- and warm-temperate zones in the eastern North Atlantic. PALAIOS 2013, 28, 386-393. [CrossRef]

51. García-Escárzaga, A.; Gutiérrez-Zugasti, I.; Schöne, B.R.; Cobo, A.; Martín-Chivelet, J.; González-Morales, M.R. Growth patterns of the topshell Phorcus lineatus (da Costa, 1778) in northern Iberia deduced from shell sclerochronology. Chem. Geol. 2019, 526, 49-61. [CrossRef]

52. Schöne, B.R. The curse of physiology-challenges and opportunities in the interpretation of geochemical data from mollusk shells. Geo-Mar. Lett 2008, 28, 269-285. [CrossRef]

53. Reynaud, S.; Ferrier-Pagès, C.; Meibom, A.; Mostefaoui, S.; Mortlock, R.; Fairbanks, R.; Allemand, D. Light and temperature effects on $\mathrm{Sr} / \mathrm{Ca}$ and $\mathrm{Mg} / \mathrm{Ca}$ ratios in the scleractinian coral Acropora sp. Geochim. Cosmochim. Acta 2007, 71, 354-362. [CrossRef]

54. Raddatz, J.; Liebetrau, V.; Rüggeberg, A.; Hathorne, E.; Krabbenhöft, A.; Eisenhauer, A.; Böhm, F.; Vollstaedt, H.; Fietzke, J.; López Correa, M.; et al. Stable Sr-isotope, $\mathrm{Sr} / \mathrm{Ca}, \mathrm{Mg} / \mathrm{Ca}, \mathrm{Li} / \mathrm{Ca}$ and $\mathrm{Mg} / \mathrm{Li}$ ratios in the scleractinian cold-water coral Lophelia pertusa. Chem. Geol. 2013, 352, 143-152. [CrossRef]

55. Evans, D.; Erez, J.; Oron, S.; Müller, W. Mg/Ca-temperature and seawater-test chemistry relationships in the shallow-dwelling large benthic foraminifera Operculina ammonoides. Geochim. Cosmochim. Acta 2015, 148, 325-342. [CrossRef]

56. Freitas, P.S.; Clarke, L.J.; Kennedy, H.; Richardson, C.A. The potential of combined Mg/Ca and $\delta^{18} \mathrm{O}$ measurements within the shell of the bivalve Pecten maximus to estimate seawater $\delta^{18} \mathrm{O}$ composition. Chem. Geol. 2012, 291, 286-293. [CrossRef]

57. Cobo, A.; García-Escárzaga, A.; Gutiérrez-Zugasti, I.; Setien-Marquinez, J.; González-Morales, M.R.; Higuera, J.M. Automated measurement of Magnesium/Calcium ratios in gastropod shells using Laser-Induced Breakdown Spectroscopy (LIBS) for paleoclimatic applications. Appl. Spectrom. 2017, 71, 1-9. [CrossRef]

58. Hausmann, N.; Prendergast, A.L.; Lemonis, A.; Zech, J.; Roberts, P.; Siozos, P.; Anglos, D. Extensive elemental mapping unlocks $\mathrm{Mg} / \mathrm{Ca}$ ratios as climate proxy in seasonal records of Mediterranean limpets. Sci. Rep. 2019, 9, 3698. [CrossRef]

59. Freitas, P.; Clarke, L.J.; Kennedy, H.; Richardson, C.; Abrantes, F. Mg/Ca, Sr/Ca, and stable-isotope $\left(\delta^{18} \mathrm{O}\right.$ and $\left.\delta^{13} \mathrm{C}\right)$ ratio profiles from the fan mussel Pinna nobilis: Seasonal records and temperature relationships. Geochem. Geophys. Geosyst. 2005, 6. [CrossRef] 
60. Wanamaker, A.D.; Kreutz, K.J.; Wilson, T.; Borns, H.W., Jr.; Introne, D.S.; Feindel, S. Experimentally determined Mg/Ca and $\mathrm{Sr} / \mathrm{Ca}$ ratios in juvenile bivalve calcite for Mytilus edulis: Implications for paleotemperature reconstructions. Geo-Mar. Lett. 2008, 28, 359-368. [CrossRef]

61. Schöne, B.R.; Zhang, Z.; Radermacher, P.; Thébault, J.; Jacob, D.E.; Nunn, E.V.; Maurer, A.-F. Sr/Ca and Mg/Ca ratios of ontogenetically old, long-lived bivalve shells (Arctica islandica) and their function as paleotemperature proxies. Palaeogeogr. Palaeoclimatol. Palaeoecol. 2011, 302, 52-64. [CrossRef]

62. Poulain, C.; Gillikin, D.P.; Thébault, J.; Munaron, J.-M.; Bohn, M.; Robert, R.; Paulet, Y.-M.; Lorrain, A. An evaluation of Mg/Ca, $\mathrm{Sr} / \mathrm{Ca}$, and $\mathrm{Ba} / \mathrm{Ca}$ ratios as environmental proxies in aragonite bivalve shells. Chem. Geol. 2015, 396, 42-50. [CrossRef]

63. Marali, S.; Schöne, B.R.; Mertz-Kraus, R.; Griffin, S.M.; Wanamaker, A.D.; Butler, P.G.; Holland, H.A.; Jochum, K.P. Reproducibility of trace element time-series ( $\mathrm{Na} / \mathrm{Ca}, \mathrm{Mg} / \mathrm{Ca}, \mathrm{Mn} / \mathrm{Ca}, \mathrm{Sr} / \mathrm{Ca}$, and $\mathrm{Ba} / \mathrm{Ca}$ ) within and between specimens of the bivalve Arctica islandica-A LA-ICP-MS line scan study. Palaeogeogr. Palaeoclimatol. Palaeoecol. 2017, 484, 109-128. [CrossRef]

64. Wanamaker, A.D.; Gillikin, D.P. Strontium, magnesium, and barium incorporation in aragonitic shells of juvenile Arctica islandica: Insights from temperature controlled experiments. Chem. Geol. 2019, 526, 117-129. [CrossRef]

65. Graniero, L.; Surge, D.; Gillikin, D.; Godino, I.B.; Álvarez, M. Assessing elemental ratios as a paleotemperature proxy in the calcite shells of patelloid limpets. Palaeogeogr. Palaeoclimatol. Palaeoecol. 2017, 465, 376-385. [CrossRef]

66. Gutiérrez-Zugasti, I.; Andersen, S.H.; Araújo, A.C.; Dupont, C.; Milner, N.; Monge-Soares, A.M. Shell midden research in Atlantic Europe: State of the art, research problems and perspectives for the future. Quat. Int. 2011, 239, 70-85. [CrossRef]

67. García-Escárzaga, A.; Gutiérrez-Zugasti, I. The role of shellfish in human subsistence during the Mesolithic of Atlantic Europe: An approach from meat yield estimations. Quat. Int. 2020. [CrossRef]

68. García-Escárzaga, A.; Moncayo, S.; Gutiérrez-Zugasti, I.; González-Morales, M.R.; Martín-Chivelet, J.; Cáceres, J. Mg/Ca ratios measured by laser induced breakdown spectroscopy (LIBS): A new approach to decipher environmental conditions. J. Anal. At. Spectrom. 2015, 30, 1913-1919. [CrossRef]

69. García-Escárzaga, A.; Clarke, L.J.; Gutiérrez-Zugasti, I.; González-Morales, M.R.; Martinez, M.; López-Higuera, J.-M.; Cobo, A. $\mathrm{Mg} /$ Ca profiles within archaeological mollusc (Patella vulgata) shells: Laser-Induced Breakdown Spectroscopy compared to Inductively Coupled Plasma-Optical Emission Spectrometry. Spectrochim. Acta Part B Atomic Spectrosc. 2018, 148, 8-15. [CrossRef]

70. Hausmann, N.; Robson, H.K.; Hunt, C. Annual growth patterns and interspecimen variability in Mg/Ca records of archaeological Ostrea edulis (European Oyster) from the Late Mesolithic site of Conors Island. Open Quat. 2019, 5, 9. [CrossRef]

71. Ciucci, A.; Corsi, M.; Palleschi, V.; Rastelli, S.; Salvetti, A.; Tognoni, E. New procedure for quantitative elemental analysis by laser-induced plasma spectroscopy. Appl. Spectrosc. 1999, 53, 960-964. [CrossRef]

72. García-Escárzaga, A.; Gutiérrez-Zugasti, I.; González-Morales, M.R.; Arrizabalaga, A.; Zech, J.; Roberts, P. Shell sclerochronology and stable oxygen isotope ratios from the limpet Patella depressa Pennant, 1777: Implications for palaeoclimate reconstruction and archaeology in northern Spain. Palaeogeogr. Palaeoclimatol. Palaeoecol. 2020, 560, 110023. [CrossRef]

73. Gutiérrez-Zugasti, I.; García-Escárzaga, A.; Martín-Chivelet, J.; González-Morales, M.R. Determination of sea surface temperatures using oxygen isotope ratios from Phorcus lineatus (Da Costa, 1778) in northern Spain: Implications for paleoclimate and archaeological studies. Holocene 2015, 25, 1002-1014. [CrossRef]

74. Gutiérrez-Zugasti, I.; Suárez-Revilla, R.; Clarke, L.J.; Schöne, B.R.; Bailey, G.N.; González-Morales, M.R. Shell oxygen isotope values and sclerochronology of the limpet Patella vulgata Linnaeus 1758 from northern Iberia: Implications for the reconstruction of past seawater temperatures. Palaeogeogr. Palaeoclimatol. Palaeoecol. 2017, 475, 162-175. [CrossRef]

75. Hahn, D.W.; Omenetto, N. Laser-induced breakdown spectroscopy (LIBS), part I: Review of basic diagnostics and plasma-particle interactions: Still-challenging issues within the analytical plasma community. Appl. Spectrosc. 2010, 64, 335A-366A. [CrossRef] [PubMed]

76. MacClintock, C. Shell structure of patteloid and bellerophontoid gastropods (Mollusca). Peabody Mus. Nat. Hist. Yale Univ. Bull. 1967, 22, 1-140.

77. Vautard, R.; Ghil, M. Singular spectrum analysis in nonlinear dynamics, with applications to paleoclimatic time series. Phys. D Nonlinear Phenom. 1989, 35, 395-424. [CrossRef]

78. Ghil, M.; Allen, M.; Dettinger, M.; Ide, K.; Kondrashov, D.; Mann, M.; Robertson, A.W.; Saunders, A.; Tian, Y.; Varadi, F. Advanced spectral methods for climatic time series. Rev. Geophys. 2002, 40. [CrossRef]

79. Takahashi, T.; Thornton, B. Quantitative methods for compensation of matrix effects and self-absorption in Laser Induced Breakdown Spectroscopy signals of solids. Spectrochim. Acta Part B Atomic Spectrosc. 2017, 138, 31-42. [CrossRef]

80. Palleschi, V. Understanding the source of signal fluctuations in laser-induced breakdown spectroscopy analytical applications. Front. Phys. 2020, 16, 22503. [CrossRef]

81. Heinemann, A.; Hiebenthal, C.; Fietzke, J.; Eisenhauer, A.; Wahl, M. Disentangling the biological and environmental control of M. edulis shell chemistry. Geochem. Geophys. Geosyst. 2011, 12. [CrossRef]

82. Mouchi, V.; De Rafélis, M.; Lartaud, F.; Fialin, M.; Verrecchia, E. Chemical labelling of oyster shells used for time-calibrated high-resolution $\mathrm{Mg}$ /ca ratios: A tool for estimation of past seasonal temperature variations. Palaeogeogr. Palaeoclimatol. Palaeoecol. 2013, 373, 66-74. [CrossRef]

83. Milano, S.; Schöne, B.R.; Gutiérrez-Zugasti, I. Oxygen and carbon stable isotopes of Mytilus galloprovincialis Lamarck, 1819 shells as environmental and provenance proxies. Holocene 2019, 30, 65-76. [CrossRef] 
84. Trofimova, T.; Andersson, C.; Bonitz, F.G.W.; Pedersen, L.-E.R.; Schöne, B.R. Reconstructing early Holocene seasonal bottom-water temperatures in the northern North Sea using stable oxygen isotope records of Arctica islandica shells. Palaeogeogr. Palaeoclimatol. Palaeoecol. 2021, 567, 110242. [CrossRef]

85. Schöne, B.R.; Freyre Castro, A.D.; Fiebig, J.; Houk, S.D.; Oschmann, W.; Kröncke, I. Sea surface water temperatures over the period 1884-1983 reconstructed from oxygen isotope ratios of a bivalve mollusk shell (Arctica islandica, southern North Sea). Palaeogeogr. Palaeoclimatol. Palaeoecol. 2004, 212, 215-232. [CrossRef]

86. García-Escárzaga, A. Paleoclima y Aprovechamiento de Recursos Costeros Durante el Mesolitico en la Región Cantábrica (N de Iberia); BAR Publishing: Oxford, UK, 2020.

87. Mannino, M.A.; Spiro, B.F.; Thomas, K.D. Sampling shells for seasonality: Oxygen isotope analysis on shell carbonates of the inter-tidal gastropod Monodonta lineata (da Costa) from populations across its modern range and from a Mesolithic site in southern Britain. J. Archaeol. Sci. 2003, 30, 667-679. [CrossRef]

88. Burchell, M.; Cannon, A.; Hallmann, N.; Schwarcz, H.P.; Schöne, B.R. Inter-site variability in the season of shellfish collection on the central coast of British Columbia. J. Archaeol. Sci. 2013, 40, 626-636. [CrossRef]

89. Hausmann, N.; Meredith-Williams, M. Seasonal patterns of coastal exploitation on the Farasan Islands, Saudi Arabia. J. Isl. Coast. Archaeol. 2017, 12, 360-379. [CrossRef]

90. Fenger, T.; Surge, D.; Schöne, B.; Milner, N. Sclerochronology and geochemical variation in limpet shells (Patella vulgata): A new archive to reconstruct coastal sea surface temperature. Geochem. Geophys. Geosyst. 2007, 8, 7. [CrossRef]

91. Prendergast, A.L.; Schöne, B.R. Oxygen isotopes from limpet shells: Implications for palaeothermometry and seasonal shellfish foraging studies in the Mediterranean. Palaeogeogr. Palaeoclimatol. Palaeoecol. 2017, 484, 33-47. [CrossRef]

92. Mannino, M.; Thomas, K.; Leng, M.; Piperno, M.; Tusa, S.; Tagliacozzo, A. Marine resources in the Mesolithic and Neolithic at the Grotta dell'Uzzo (Sicily): Evidence from isotope analyses of marine shells. Archaeometry 2007, 49, 117-133. [CrossRef] 